\title{
KEMAMPUAN METODE KOMBINASI FILTRASI FITOREMEDIASI TANAMAN TERATAI DAN ECENG GONDOK DALAM MENURUNKAN KADAR BOD DAN COD AIR LIMBAH INDUSTRI TAHU Ain Khaer ${ }^{1}$ dan Evi Nursyafitri ${ }^{2}$ \\ 1,2Jurusan Kesehatan Lingkungan Poltekkes Kemenkes Makassar evinursyafitri87@gmail.com
}

\begin{abstract}
Tofu industry activities in Indonesia are dominated by small-scale enterprises with limited capital. Tofu production is still done with simple technology, so that the level of efficiency of water use and soybean raw material is still felt low and the level of waste production is very high. This study aims to determine the ability of phytoremediation filtration combination method in lowering BOD and COD content of industrial waste water. Research type is experiment with Pre-Pos test design, that is test to sample before and after passed on processing media. Laboratory analysis by Winkler Titration method and titration of Reflux method. Processing and presentation of data in the form of tables and graphs. The data were analyzed descriptively by seeing the difference of decrease after going through treatment on processing media. The results showed that $B O D$ and $C O D$ concentrations before treatment were $1035.84 \mathrm{mg} / \mathrm{I}$ and $2196.5 \mathrm{mg} / \mathrm{l}$, respectively, where the average yield of BOD for lotus tubes was $558.88 \mathrm{mg} / \mathrm{l}(46.05 \%)$ and in water hyacinth tube was $548.42 \mathrm{mg} / \mathrm{L} \mathrm{(47.02 \% )} \mathrm{and} \mathrm{average}$ yield of COD decrease for lotus tube was $1164.36 \mathrm{mg} / \mathrm{I}(44.46 \%)$ and in water hyacinth tube was $1164.21 \mathrm{mg} / \mathrm{I}$ (44.47\%). It was concluded that the result of the decrease of $B O D$ and $C O D$ content of industrial wastewater know after processing by filtration method combination of phytoremediation of lotus plant and water hyacinth, able to decrease BOD and COD. It is recommended that the industry knows to process waste before disposal into the environment one of them is physical processing with simple filtration media such as charcoal and gravel and biological by utilizing lotus plants and water hyacinth.
\end{abstract}

Keywords: Filtration, Phytoremediation, Lotus, Water Hyacinth, BOD, COD, Tofu Waste Water

\section{ABSTRAK}

Kegiatan industri tahu di Indonesia didominasi oleh usaha-usaha skala kecil dengan modal yang terbatas. Produksi tahu masih dilakukan dengan teknologi yang sederhana, sehingga tingkat efisiensi penggunaan air dan bahan baku kedelai dirasakan masih rendah dan tingkat produksi limbahnya sangat tinggi. Penelitian ini bertujuan untuk mengetahui kemampuan metode kombinasi filtrasi fitoremediasi dalam menurunkan kadar BOD dan COD air limbah industri tahu. Jenis penelitian adalah eksperimen dengan desain Pre-Pos test, yaitu pengujian terhadap sampel sebelum dan sesudah dilewatkan pada media pengolahan. Analisa laboratorium dengan metode Titrasi Winkler dan titrasi metode Refluks. Pengolahan dan penyajian data dalam bentuk tabel dan grafik. Data dianalisis secara deskriptif dengan melihat perbedaan penurunan setelah melalui perlakuan pada media pengolahan. Hasil penelitian menunjukkan bahwa kadar BOD dan COD sebelum perlakuan masing-masing sebesar $1035.84 \mathrm{mg} / \mathrm{l}$ dan $2196.5 \mathrm{mg} / \mathrm{l}$ dimana rata-rata hasil penurunan BOD untuk bak teratai sebesar $558.88 \mathrm{mg} / \mathrm{l}(46.05 \%)$ dan pada bak eceng gondok sebesar $548.42 \mathrm{mg} / \mathrm{l}(47.02 \%)$ dan rata-rata hasil penurunan COD untuk bak teratai sebesar $1164.36 \mathrm{mg} / \mathrm{l}(44.46 \%)$ dan pada bak eceng gondok sebesar $1164.21 \mathrm{mg} / \mathrm{l}$ (44.47\%). Disimpulkan bahwa hasil penurunan kadar BOD dan COD air limbah industri tahu sesudah pengolahan dengan metode filtrasi kombinasi fitoremediasi tanaman teratai dan eceng gondok, mampu menurunkan kadar BOD dan COD. Disarankan agar pihak industri tahu perlu mengolah limbah sebelum dibuang ke lingkungan salah satunya yaitu pengolahan fisik dengan media filtrasi sederhana seperti arang dan kerikil dan biologis dengan memanfaatkan tanaman teratai dan eceng gondok.

\section{Kata Kunci : Filtrasi, Fitoremediasi, Teratai, Eceng Gondok, BOD, COD, Air Limbah Tahu}

\section{PENDAHULUAN}

Masalah pencemaran air limbah di Indonesia tidak hanya disebabkan oleh industri besar, namun juga disebabkan oleh industri skala kecil (rumah tangga) yang kurang mengelola air buangannya. Salah satu industri skala kecil yang sekarang berkembang pesat dan memberikan kontribusi pada penyerapan tenaga kerja dan pengembangan ekonomi daerah adalah industri tahu. Kegiatan industri tahu di Indonesia didominasi oleh usaha-usaha skala kecil dengan modal yang terbatas. Dari segi lokasi usaha ini juga sangat tersebar di seluruh wilayah Indonesia. Sumber daya manusia yang terlibat pada umumnya bertaraf pendidikan yang relatif rendah. Produksi tahu masih dilakukan dengan teknologi yang sederhana, dibuat oleh pengrajin sendiri dalam skala industri rumah tangga atau industri kecil sehingga tingkat efisiensi penggunaan air dan bahan baku kedelai dirasakan masih rendah dan tingkat produksi limbahnya sangat tinggi.

Oksigen terlarut pada air limbah dipengaruhi oleh kandungan bahan organik dari suatu limbah yang biasanya dinyatakan dengan parameter BOD atau "Biochemical Oxygen Demand". BOD dapat didefinisikan sebagai jumlah oksigen terlarut yang digunakan oleh mikroba, bila suatu contoh air diinkubasikan dalam keadaan gelap (biasanya 5 hari) pada 
Jurnal Sulolipu : Media Komunikasi Sivitas Akademika dan Masyarakat

Vol. 17 No.II 2017

e-issn : 2622-6960, $p$-issn : 0854-624X

suhu tertentu $\left(20^{\circ} \mathrm{C}\right)$. Oleh karena oksigen dibutuhkan untuk oksidasi bahan organik, maka BOD menunjukkan indikasi kasar kandungan organik dalam limbah (Jenie \& Rahayu, 1996). Adapun parameter COD atau "Chemical Oxygen Demand" merupakan kebutuhan oksigen dalam proses oksidasi secara kimia.

Filtrasi merupakan pengolahan dengan cara fisika, yang merupakan metode pemisahan sebagian dari beban pencemaran khususnya padatan atau koloid dari limbah cair dengan memanfaatkan gaya-gaya fisika. Dalam pengolahan limbah industri tahu secara fisika, proses yang dapat digunakan antara lain adalah filtrasi dan pengendapan (sedimentasi).

Fitoremediasi merupakan penggunaan tumbuhan untuk menghilangkan, memindahkan, menstabilkan, atau menghancurkan bahan pencemar baik senyawa organik maupun anorganik. Pada pengolahan limbah cair yang menggunakan tumbuhan air terjadi proses penyaringan dan penyerapan oleh akar ataupun batang tumbuhan air, proses pertukaran dan penyerapan ion, dan tumbuhan air juga berperan dalam menstabilkan pengaruh iklim, angin, cahaya matahari dan suhu.

Teratai (Nympahea firecrest) merupakan jenis tumbuhan air yang termasuk kedalam kelompok floating leaves yaitu akar berada di dasar perairan sedangkan daunnya berada di permukaan air, tanaman Teratai telah banyak digunakan untuk penelitian sebagai fitoremediasi. Seperti yang pernah dilakukan Staf Peneliti Puslit Limnologi-LIPI Universitas Pakuan Bogor pembuatan lahan basah buatan sistem aliran permukaan dan aliran bawah permukaan yang ditanami dengan Teratai dan Ganggang mampu menurunkan kadar total nitrogen (TN) dan total fosfor (TP) air limbah pencucian dari laboratorium analisis kimia. Penurunan kadar TN sistem aliran bawah permukaan $(99,84 \%$, yaitu dari 8,193 ke 0,013 $\mathrm{mg} / \mathrm{L}$ ), sedangkan penurunan kadar TP lebih baik pada sistem permukaan $(100 \%$, yaitu dari 4,861 ke $0 \mathrm{mg} / \mathrm{L}$ ).

Eceng gondok merupakan tanaman yang tumbuh di kolam-kolam dangkal, tanah basah dan rawa, aliran air yang lambat, danau, tempat penampungan air dan sungai. Tumbuhan ini dapat beradaptasi dengan perubahan yang ekstrem dari ketinggian air, arus air, dan perubahan ketersediaan nutrien, $\mathrm{pH}$, temperatur dan racun-racun dalam air. Walaupun eceng gondok dianggap sebagai gulma di perairan, tetapi sebenarnya ia berperan dalam menangkap polutan logam berat, maupun kandungan organik dalam air limbah (Wikipedia, 2016).

Pada penelitian (Dharma Yoga, Nindra dan Eko Hartini, 2015) tentang efektivitas tanaman teratai (Nympahea firecrest) dan eceng gondok (Eichhornia crassipes) dalam menurunkan kadar BOD pada limbah cair industri tahu yang diperoleh dari pengrajin tahu Setia Makmur Jl.Cempaka Selatan RT 2/RW 1 Lemper Kidul Semarang Selatan, mendapatkan hasil yang sangat berpengaruh terhadap penurunan kadar BOD.

Pengamatan dilakukan pada hari 6,12 , dan 18. Perlakuan yang menggunakan tanaman eceng gondok dan teratai tersebut mempunyai persentase penurunan BOD yang sangat besar, yakni dari 745,72 mg/l menjadi 57,42 mg/l (untuk tanaman teratai) dan dari $1131,38 \mathrm{mg} / \mathrm{l}$ menjadi $52,42 \mathrm{mg} / \mathrm{l}$ (untuk tanaman eceng gondok) sehingga penggunaan tanaman tersebut efektif dan efisien.

Atas dasar pemikiran di atas sehingga penulis tertarik untuk meneliti "Kemampuan Metode Kombinasi Filtrasi Fitoremediasi Tanaman Teratai Dan Eceng Gondok Dalam Menurunkan Kadar BOD dan COD Air Limbah Industri Tahu"

\section{METODE PENELITIAN}

\section{Lokasi Penelitian}

Lokasi pengambilan sampel air limbah industri tahu adalah di Jl. Abu Bakar Lambogo, sedangkan pengambilan tanaman teratai dan eceng gondok di Jl. Biring Romang. Lokasi untuk melakukan pemeriksaan kadar BOD dan COD adalah di Laboratorium Jurusan Kesehatan Lingkungan Politeknik Kesehatan Makassar.

\section{Desain dan Variabel Penelitian}

Jenis penelitian yang digunakan adalah eksperimen yaitu untuk melihat penurunan kadar BOD dan COD pada air limbah industri tahu dilakukan dengan metode kombinasi filtrasi fitoremediasi tanaman teratai dan eceng gondok dengan desain Pre-Pos test, yaitu pengujian terhadap sampel sebelum dan sesudah dilewatkan pada media pengolahan.

Variabel dalam penelitian ini adalah proses filtrasi dan fitoremediasi dengan menggunakan tanaman teratai dan eceng gondok dalam menurunkan kadar BOD dan 
Jurnal Sulolipu : Media Komunikasi Sivitas Akademika dan Masyarakat

Vol. 17 No.II 2017

e-issn : 2622-6960, p-issn : 0854-624X

COD air limbah tahu dengan desain sebagai berikut:

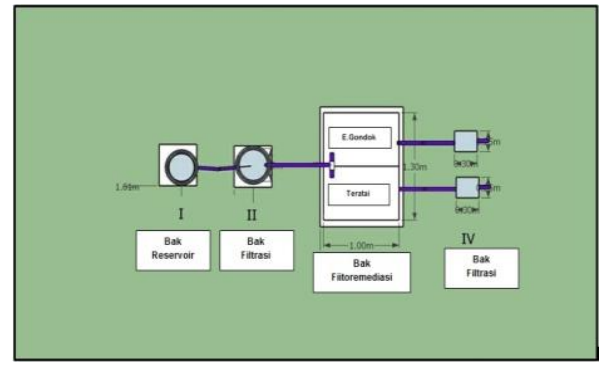

Gambar 1

Desain Pengolahan

\section{Sampel}

Sampel dalam penelitian ini adalah air limbah industri tahu yang diambil di industri tahu rumahan Jl.Abu Bakar Lambogo. Volume sampel adalah 70 liter.

\section{Pengumpulan Data}

a. Data Primer

Data primer diperoleh melalui pemeriksaan kadar BOD dan COD di Laboratorium Poltekkes Kemenkes Makassar Jurusan Kesehatan Lingkungan, baik sebelum maupun sesudah pengolahan.

b. Data Sekunder

Data sekunder diperoleh melalui penelusuran kepustakaan berupa referensi hasil penelitian sebelumnya, jurnal, artikel, maupun laporan pemerintah yang terkait seperti departemen perindustrian.

\section{Analisis Data}

Data dianalisa secara deskriptif yaitu dengan mengetahui besarnya perbedaan penurunan kadar BOD dan COD setelah perlakuan dengan metode kombinasi filtrasi fitoremediasi tanaman teratai dan eceng gondok serta membandingkan dengan Baku Mutu Lingkungan.

\section{HASIL PENELITIAN}

\section{Hasil Pemeriksaan Kadar Awal BOD dan COD}

Hasil pemeriksaan air limbah yang dilaksanakan pada tanggal 29 Mei 2017 diperoleh kadar BOD awal sebesar 1035.84 $\mathrm{mg} / \mathrm{l}$ dan kadar COD awal sebesar 2196.5 $\mathrm{mg} / \mathrm{l}$ jika dibandingkan dengan standar Peraturan Gubernur Sulawesi - Selatan no. 69 Tahun 2010, khususnya untuk industri tahu kadar BOD dan COD tersebut belum memenuhi syarat, yaitu kadar maksimum BOD 150 mg/l dan COD 300 mg/L.

\section{Hasil Pemeriksaan Kadar BOD dan COD Setelah Pengolahan \\ Tabel 1}

Rata-rata Penurunan Kadar BOD dengan

Menggunakan Metode Kombinasi Filtrasi

Fitoremediasi Tanaman Eceng Gondok Dan Teratai

\begin{tabular}{|c|c|c|c|c|c|c|}
\hline \multirow{3}{*}{ No } & \multirow{3}{*}{$\begin{array}{c}\text { Jenis } \\
\text { Tanam } \\
\text { an }\end{array}$} & \multirow{3}{*}{$\begin{array}{c}\text { Pem } \\
\text { eriks } \\
\text { aan }\end{array}$} & \multirow{2}{*}{\multicolumn{2}{|c|}{$\begin{array}{c}\text { Kadar BOD } \\
(\mathrm{mg} / \mathrm{L})\end{array}$}} & \multicolumn{2}{|c|}{$\begin{array}{l}\text { Penyisihan } \\
\text { Penurunan }\end{array}$} \\
\hline & & & & & \multirow{2}{*}{$\begin{array}{l}\text { Kadar } \\
\text { (mg/L) }\end{array}$} & \multirow{2}{*}{$\begin{array}{c}\begin{array}{c}\text { Pers } \\
\text { enta } \\
\text { se }\end{array} \\
(\%)\end{array}$} \\
\hline & & & Sebelum & $\begin{array}{c}\text { Sesu } \\
\text { dah }\end{array}$ & & \\
\hline \multirow{3}{*}{1} & \multirow{3}{*}{$\begin{array}{c}\text { Eceng } \\
\text { Gondo } \\
\text { k }\end{array}$} & 1 & 1035.84 & $\begin{array}{c}700.2 \\
5\end{array}$ & 335.59 & 32.40 \\
\hline & & II & 1035.84 & $\begin{array}{c}566.5 \\
6\end{array}$ & 468.44 & 44.30 \\
\hline & & III & 1035.84 & $\begin{array}{c}378.4 \\
5\end{array}$ & 657.39 & 63.46 \\
\hline \multirow{3}{*}{2} & \multirow{3}{*}{ Teratai } & I & 1035.84 & $\begin{array}{c}710.3 \\
5\end{array}$ & 325.49 & 31.42 \\
\hline & & II & 1035.84 & $\begin{array}{c}576.9 \\
5\end{array}$ & 458.89 & 44.30 \\
\hline & & III & 1035.84 & $\begin{array}{c}389.3 \\
4\end{array}$ & 646.50 & 62.41 \\
\hline \multirow{2}{*}{$\begin{array}{l}\text { Rat } \\
\text { a- } \\
\text { rata }\end{array}$} & \multicolumn{2}{|c|}{ Eceng Gondok } & 1035.84 & $\begin{array}{c}548.4 \\
2\end{array}$ & 487.14 & 47.02 \\
\hline & \multicolumn{2}{|c|}{ Teratai } & 1035.84 & $\begin{array}{c}558.8 \\
8\end{array}$ & 476.96 & 46.05 \\
\hline
\end{tabular}




\section{Tabel 2}

Rata-rata Penurunan Kadar COD dengan Menggunakan Metode Kombinasi Filtrasi Fitoremediasi Tanaman Eceng Gondok Dan Teratai

\begin{tabular}{|c|c|c|c|c|c|c|}
\hline \multirow{3}{*}{$\begin{array}{l}\mathbf{N} \\
\mathbf{O}\end{array}$} & \multirow{3}{*}{$\begin{array}{c}\text { Jeni } \\
\text { s } \\
\text { Tana } \\
\text { man }\end{array}$} & \multirow{3}{*}{$\begin{array}{l}\text { Pemeri } \\
\text { ksaan }\end{array}$} & \multicolumn{2}{|c|}{$\begin{array}{c}\text { Kadar COD } \\
(\mathrm{mg} / \mathrm{L})\end{array}$} & \multicolumn{2}{|c|}{$\begin{array}{l}\text { Penyisihan } \\
\text { Penurunan }\end{array}$} \\
\hline & & & & & \multirow{2}{*}{$\begin{array}{c}\mathrm{Ka} \\
\text { dar } \\
(\mathrm{m} \\
\mathrm{g} / \mathrm{L} \\
)\end{array}$} & \multirow{2}{*}{$\begin{array}{c}\text { Perse } \\
\text { ntase }\end{array}$} \\
\hline & & & $\begin{array}{l}\text { Sebe } \\
\text { lum }\end{array}$ & $\begin{array}{l}\text { Sesu } \\
\text { dah }\end{array}$ & & \\
\hline \multirow[b]{3}{*}{1} & \multirow{3}{*}{$\begin{array}{c}\text { Ecen } \\
\text { g } \\
\text { Gond } \\
\text { ok }\end{array}$} & I & $\begin{array}{l}2196 \\
.5\end{array}$ & 1389 & $\begin{array}{l}707 \\
.3\end{array}$ & 33.73 \\
\hline & & II & $\begin{array}{l}2196 \\
.5\end{array}$ & 1105 & $\begin{array}{l}991 \\
.4\end{array}$ & 47.28 \\
\hline & & III & $\begin{array}{l}2196 \\
.5\end{array}$ & $\begin{array}{l}998 . \\
3\end{array}$ & $\begin{array}{l}109 \\
8\end{array}$ & 52.38 \\
\hline \multirow[b]{3}{*}{2} & \multirow[b]{3}{*}{$\begin{array}{c}\text { Terat } \\
\text { ai }\end{array}$} & I & $\begin{array}{l}2196 \\
.5\end{array}$ & 1391 & $\begin{array}{l}705 \\
.9\end{array}$ & 33.67 \\
\hline & & II & $\begin{array}{l}2196 \\
.5\end{array}$ & 1103 & $\begin{array}{l}993 \\
.5\end{array}$ & 47.38 \\
\hline & & III & $\begin{array}{l}2196 \\
.5\end{array}$ & $\begin{array}{l}999 . \\
5\end{array}$ & $\begin{array}{l}109 \\
7\end{array}$ & 52.33 \\
\hline \multirow{2}{*}{$\begin{array}{l}\mathrm{R} \\
\text { at } \\
\mathrm{a} \\
- \\
\text { rat } \\
\mathrm{a}\end{array}$} & \multicolumn{2}{|c|}{ Eceng Gondok } & $\begin{array}{l}2196 \\
.5\end{array}$ & 1164 & $\begin{array}{l}932 \\
.3\end{array}$ & 44.47 \\
\hline & \multicolumn{2}{|c|}{ Teratai } & $\begin{array}{l}2196 \\
.5\end{array}$ & 1164 & $\begin{array}{l}932 \\
.1\end{array}$ & 44.46 \\
\hline
\end{tabular}

\section{PEMBAHASAN}

1. Penurunan Kadar BOD Setelah Pengolahan dengan Metode Kombinasi Filtrasi Fitoremediasi Tanaman Teratai dan Eceng Gondok

BOD adalah jumlah oksigen yang dibutuhkan oleh mikroorganisme di dalam air lingkungan untuk memecah (mendegradasi) bahan buangan organik yang ada di dalam air limbah lingkungan tersebut.

Berdasarkan hasil penelitian yang telah dilakukan dapat dilihat pada tabel 5.1 menunjukkan bahwa hasil pemeriksaan sampel awal untuk kadar BOD sebesar $1035.84 \mathrm{mg} / \mathrm{L}$. Setelah dilakukan pengolahan dengan metode kombinasi filtrasi fitoremediasi tanaman teratai dan eceng gondok menunjukkan adanya penurunan pada hasil pemeriksaan. Dengan rata-rata penurunan dari bak tanaman eceng gondok sebesar $548.42 \mathrm{mg} / \mathrm{l}$ dengan rata-rata persentase penurunan sebesar $47.02 \%$, untuk tanaman teratai diperoleh rata-rata penurunan sebesar $558.88 \mathrm{mg} / \mathrm{l}$ dengan rata-rata persentase penurunan sebesar $46.05 \%$.

Penurunan tersebut disebabkan oleh proses fitoremediasi yang terjadi pada tanaman teratai dan eceng gondok, dimana kedua tanaman ini mampu menyerap zat-zat organik yang terdapat pada air limbah tahu tersebut. Berdasarkan teori bahwa fitoremediasi merupakan suatu sistem dimana tanaman tertentu yang bekerja sama dengan micro-organisme dalam media (tanah, koral, dan air) dapat mengubah zat kontaminan (pencemar/pollutan) menjadi kurang atau tidak berbahaya (Anam, 2013) dalam

(Siswandari, Hindun, \& Sukarsono, 2016). Penggunaan tanaman teratai dan eceng gondok dimaksudkan agar tanaman ini menyerap zat-zat organik yang ada pada air limbah. Sebagiamana penelitian Yoga, Nindra, \& Hartini (2015) tentang Efektivitas Tanaman Teratai (Nympahea Firecrest) Dan Eceng Gondok (Eichhornia Crassipes) Dalam Menurunkan Kadar BOD Pada Limbah Cair Industri Tahu.

Menunjukkan hasil bahwa penurunan kadar BOD menjadi $33,68 \mathrm{mg} / \mathrm{l}$ pada eceng gondok dan pada teratai sebesar 63,51 mg/l dimana kadar BOD awal sebesar $1280 \mathrm{mg} / \mathrm{L}$. Hal inilah yang menyebabkan terjadinya penurunan.

Selain itu pada penelitian sebelumnya juga yang dilakukan oleh Djibran, Isa, \& Sihaloho (2015) tentang Fitoremediasi Air Yang Terkontaminasi Fosfat Dengan Menggunakan Tanaman Teratai (Nymphea Sp). Tanaman teratai yang digunakan dalam penelitian ini diambil dari danau limboto dan ditanam kembali dalam bak fitoremediasi yang telah di beri fosfat $15 \mathrm{mg} / \mathrm{L}$ dengan variasi waktu 5,10 , 15, 20 dan 25 hari. Analisis fosfat pada tanaman teratai menggunakan spektrofotometri UV-Vis pada panjang gelombang $367 \mathrm{~nm}$. Hasil penelitian menunjukkan bahwa konsentrasi fosfat pada 
tanaman teratai berturut-turut adalah 3,101, 4,775, 2,095, 4,462 dan 3,039 mg/L. Hasil penelitian ini juga menunjukkan bahwa tanaman teratai dapat dijadikan sebagai agen fitoremediasi.

Nilai BOD dipengaruhi juga oleh adanya tanaman eceng gondok dan teratai. Keberadaan tanaman tersebut dapat menyerap zat organik yang terdapat dalam air limbah. Semakin banyak tanaman, maka semakin banyak bahan organik yang terserap dan bahan organik yang harus didegradasi oleh mikroorganisme semakin sedikit. Semakin sedikit bahan organik yang harus didegradasi oleh mikroba, maka kandungan oksigen dalam air limbah semakin tinggi. Oksigen terlarut dalam air limbah juga semakin banyak karena adanya suplai oksigen dari hasil fotosintesis tanaman. Jadi semakin banyak tanaman, maka nilai BOD semakin kecil yang berarti semakin baik kualitas air limbah tersebut.

Penurunan kadar BOD air limbah industri tahu pada penelitian ini terjadi karena proses fitoremediasi pada tanaman teratai dimulai pada proses phytoacumulation, proses dimana tumbuhan menarik zat kontaminan dari media yang berakumulasi disekitar akar kemudian zatzat kontaminan tersebut menempel pada akar tetapi tidak terserap kedalam batang tumbuhan (phytostabillization), selanjutnya zat kontaminan yang mempunyai rantai molekul yang kompleks diurai menjadi bahan yang tidak berbahaya menjadi susunan molekul yang lebih sederhana yang dapat berguna bagi tumbuhan itu sendiri (phytodegradation), proses terakhir yaitu proses menarik zat kontaminan yang tidak berbahaya yang selanjutnya diuapkan ke atmosfir (phytovolazation). Pada tanaman eceng gondok proses fitoremediasi terjadi hampir sama dengan tanaman teratai hanya tahapan dimulai pada tahap Rhizofltration yaitu proses adsorpsi atau pengendapan zat kontaminan oleh akar. Kemampuan penyerapan eceng gondok juga karena pada akarnya terdapat mikrobia rhizosfera yang mengakumulasi zat-zat pencemar. Mikrobia rhizosfera adalah bentuk simbiosis antara bakteri dengan jamur, yang mampu melakukan penguraian terhadap bahan organik maupun anorganik yang terdapat dalam air serta menggunakannya sebagai sumber nutrisi. Selain itu tingkat penurunannya juga didukung oleh proses filtrasi.

Proses filtrasi menggunakan media kerikil dan arang, dimana media kerikil ini berfungsi untuk menyaring material-material yang berukuran kasar pada air limbah tahu seperti ampas tahu yang masih halus, sedangkan proses filtrasi arang berfungsi membantu menyaring material-material yang masih lolos pada proses sebelummnya, serta arang berfungsi untuk mengurangi bau, rasa, dan warna pada air limbah tahu. Berdasarkan pendapat Sudrajat, R. (1985) dalam (Rahmah \& Mulasari, 2015) Jurnal "Pengaruh Beberapa Faktor Terhadap Sifat Arang Aktif", arang merupakan suatu bentuk karbon yang mempunyai sifat absorptif terhadap larutan ataupun uap sehingga bahan tersebut dapat berfungsi sebagai penjernih larutan, penghisap gas/ racun dan penghilang warna.

Walaupun pada pengolahan dengan metode ini terjadi penurunan pada kadar BOD namun hasil yang didapatkan masih belum memenuhi Baku Mutu sesuai dengan Pergub Sul-Sel No.69 Tahun 2010, dimana kadar BOD yang diperbolehkan khusus untuk industri pengolahan kedelai maksimum $150 \mathrm{mg} / \mathrm{l}$, rendahnya persentase penurunan dipengaruhi oleh beberapa variabel pengganggu seperti $\mathrm{pH}$, suhu, dan waktu. $\mathrm{pH}$ air limbah tahu yang rendah mempengaruhi proses pengolahan air limbah. Pengaruh yang terjadi apabila $\mathrm{pH}$ terlalu rendah adalah penurunan oksigen terlarut. Secara umum, tanaman air dapat hidup dengan $\mathrm{pH}$ berkisar antara 3,5 - 10 . Jika kondisi $\mathrm{pH}$ tidak optimum tanaman tidak mampu bertahan hidup.

Penurunan oksigen terlarut menyebabkan kurang efektifnya peran mikroba dalam memecah zat-zat organik yang terdapat pada air limbah sehingga kadar BOD menjadi lebih tinggi. Adapun suhu yang cukup tinggi pada air limbah tahu menyebabkan proses pengolahan tidak optimal karena menghambat proses penyerapan zat organik oleh tanaman dan menyebabkan kurangnya kelembapan pada tanaman ini disebabkan karena tanaman eceng gondok dan teratai mampu hidup pada tingkat kelembapan yang cukup tinggi. 
Waktu tinggal dari air limbah pada pengolahan ini juga dapat menjadi pengaruh rendahnya tingkat penurunan kadar $\mathrm{BOD}$ karena pada penelitian ini waktu tinggal air limbah pada media fitoremediasi hanya 7 hari sehingga proses adsorbsi bahan organik rendah pada limbah oleh tanaman eceng gondok maupun teratai.

2. Penurunan Kadar COD Setelah Pengolahan dengan Metode Kombinasi Filtrasi Fitoremediasi Tanaman Teratai dan Eceng Gondok

COD adalah jumlah oksigen yang diperlukan agar bahan buangan yang ada di dalam air dapat teroksidasi melalui reaksi kimia. Berdasarkan hasil penelitian yang telah dilakukan dapat dilihat pada tabel 5.2 menunjukkan bahwa hasil pemeriksaan sampel awal untuk kadar COD sebesar $2196.5 \mathrm{mg} / \mathrm{L}$. Setelah dilakukan pengolahan dengan metode kombinasi filtrasi fitoremediasi tanaman teratai dan eceng gondok menunjukkan adanya penurunan pada hasil pemeriksaan kadar COD pada bak tanaman eceng gondok dengan ratarata penurunan sebesar $1164.21 \mathrm{mg} / \mathrm{l}$ atau rata-rata persentase penurunan sebesar $44.47 \%$ dan bak tanaman teratai rata-rata penurunan sebesar 1164.36 atau rata-rata persentase penurunan sebesar $44.46 \%$.

Penurunan tersebut disebabkan oleh proses fitoremediasi yang terjadi pada tanaman teratai dan eceng gondok, dimana kedua tanaman ini mampu mengabsorbsi zat-zat organik yang terdapat pada air limbah tahu tersebut. Berdasarkan teori bahwa fitoremediasi merupakan suatu sistem dimana tanaman tertentu yang bekerja sama dengan mikroorganisme dalam media (tanah, koral, dan air) dapat mengubah zat kontaminan (pencemar/pollutan) menjadi kurang atau tidak berbahaya (Anam, 2013) dalam (Siswandari, Hindun, \& Sukarsono, 2016).

Nilai COD merupakan jumlah oksigen yang dibutuhkan untuk mengoksidasi bahan organik dalam air secara kimiawi. Jika bahan organik yang belum diolah dibuang ke badan perairan, maka bakteri akan menggunakan oksigen untuk proses pembusukannya. Nilai COD biasanya lebih tinggi dari pada nilai $B O D$ karena bahan buangan yang dapat dioksidasi melalui proses kimia lebih banyak dari pada bahan buangan yang dapat dioksidasi melalui proses biologi.

Penurunan nilai COD tersebut disebabkan karena bahan padatan telah mengendap sehingga bahan buangan di air limbah juga berkurang. Selain itu, sebagian bahan buangan telah teroksidasi dan sebagian lagi juga telah terserap oleh tanaman sehingga juga mengurangi nilai COD. Penurunan ini juga dikarenakan suplai oksigen terlarut cukup banyak terutama dari hasil fotosintesis tanaman sehingga menyebabkan dekomposisi bahan organik menjadi lebih efektif.

Sama halnya dengan BOD, penurunan kadar COD dipengaruhi juga oleh proses adsorbsi tanaman teratai dan eceng gondok karena proses fitoremediasi pada tanaman teratai dimulai pada proses phytoacumulation, proses dimana tumbuhan menarik zat kontaminan dari media yang berakumulasi disekitar akar kemudian zatzat kontaminan tersebut menempel pada akar tetapi tidak terserap kedalam batang tumbuhan (phytostabillization), selanjutnya zat kontaminan yang mempunyai rantai molekul yang kompleks diurai menjadi bahan yang tidak berbahaya menjadi susunan molekul yang lebih sederhana yang dapat berguna bagi tumbuhan itu sendiri (phytodegradation), proses terakhir yaitu proses menarik zat kontaminan yang tidak berbahaya yang selanjutnya diuapkan ke atmosfir (phytovolazation). Pada tanaman eceng gondok proses fitoremediasi terjadi hampir sama dengan tanaman teratai hanya tahapan dimulai pada tahap Rhizofltration yaitu proses adsorpsi atau pengendapan zat kontaminan oleh akar. Kemampuan penyerapan eceng gondok juga karena pada akarnya terdapat mikrobia rhizosfera yang mengakumulasi zat-zat pencemar.

Sejalan dengan penelitian yang dilakukan oleh (Hadiyanto \& Christwardana, 2012), tentang "Aplikasi Fitoremediasi Limbah Jamu Dan Pemanfaatannya Untuk Produksi Protein" Konsentrasi awal COD adalah 200 ppm. Setelah diproses dengan fitoremediasi menggunakan eceng gondok, kandungannya turun menjadi $55 \mathrm{ppm}$ sedangkan yang menggunakan teratai turun menjadi 59 ppm. Penurunan kadar COD dengan fitoremediasi menggunakan eceng 
Jurnal Sulolipu : Media Komunikasi Sivitas Akademika dan Masyarakat

Vol. 17 No.II 2017

e-issn : 2622-6960, $p$-issn : 0854-624X

gondok adalah $72,5 \%$, dan menggunakan teratai sebesar $70,5 \%$.

Melihat hasil penurunan di atas ratarata penurunan COD kedua tanaman ini hampir sama yaitu masing-masing eceng gondok sebesar $899.95 \mathrm{mg} / \mathrm{l}$ atau $44.47 \%$ dan teratai $898.88 \mathrm{mg} / \mathrm{l}$ atau $44.46 \%$. Berdasarkan hasil pengolahan dan analisa laboratorium terjadi penurunan namun hasilnya belum memenuhi syarat baku mutu lingkungan berdasarkan Peraturan gubernur Sulawesi Selatan Nomor 69 Tahun 2010 tentang Baku Mutu Dan Kriteria Kerusakan Lingkungan Hidup dimana kadar COD maksimum yaitu sebesar $300 \mathrm{mg} / \mathrm{l}$.

Hasil penurunan kadar COD di atas belum terlalu efektif atau masih relatif kecil karena di dalam proses pengolahan, kedua tanaman tersebut belum dapat menyesuaikan lingkungan baru dengan karakteristik jenis limbah baru. Selain itu sebelum proses fitoremediasi dilakukan waktu aktimalisasi hanya 6 hari saja. Sehingga proses penyesuaian tanaman dengan jenis limbahnya masih kurang.

Berdasarkan penelitian yang dilakukan oleh (Muhajir, 2013) tentang Penurunan Limbah Cair BOD dan COD pada Industri Tahu Menggunakan Tanaman Cattail (Typha Angustifolia) dengan Sistem Constructed Wetland. Hasil penelitian menunjukkan kadar COD pada industri tahu dengan variasi waktu lama penanaman terendah terjadi pada waktu tinggal hari ke 5 sebesar $1072 \mathrm{mg} / \mathrm{L}$ (12,2\%), sedangkan penurunan maksimum terjadi pada waktu tinggal hari ke 20 dengan nilai COD turun sebesar 277 mg/L (77,3\%). Sehingga waktu tinggal yang cukup lama akan menyebabkan persentase penurunan kadar COD yang tinggi pula. Sehingga waktu tinggal yang cukup lama akan menyebabkan persentase penurunan kadar COD yang tinggi pula.

\section{KESIMPULAN DAN SARAN}

\section{Kesimpulan}

a. Rata - rata penurunan kadar BOD dengan metode kombinasi filtrasi fitoremediasi tanaman teratai dan eceng gondok, air limbah industri tahu pada bak teratai sebesar $558.88 \mathrm{mg} / \mathrm{L}$ atau $46.05 \%$ dan pada bak eceng gondok sebesar $548.42 \mathrm{mg} / \mathrm{L}$ atau $47.02 \%$

b. Rata - rata penurunan kadar COD dengan metode kombinasi filtrasi fitoremediasi tanaman teratai dan eceng gondok, air limbah industri tahu pada bak teratai sebesar $1164.36 \mathrm{mg} / \mathrm{L}$ atau 44.46 $\%$ dan pada bak eceng gondok sebesar $1164.21 \mathrm{mg} / \mathrm{L}$ atau $44.47 \%$.

c. Penggunaan tanaman eceng gondok lebih efektif dibandingkan tanaman teratai, hal ini disebabkan karena tanaman eceng gondok lebih mudah melakukan adaptasi terhadap lingkungan yang baru sedangkan tanaman teratai tidak mudah untuk melakukan adaptasi dengan lingkungan yang barunya'

\section{Saran}

Kepada peneliti selanjutnya agar melakukan proses aklimatisasi tanaman yang cukup yakni minimal 2 minggu sebelum melakukan pengolahan agar tanaman dapat menyesuiakan lingkungan dengan jenis limbah yang akan diolah dengan fitoremediasi.

a. Kepada peneliti selanjutnya perlu melakukan penelitian tentang bagaimana pemanfaatan tanaman teratai dan eceng gondok setelah perlakuan fitoremediasi agar tidak menimbulkan masalah baru.

b. Kepada pihak industri tahu agar mengelola dan mengolah air limbah sebelum dibuang ke lingkungan agar tidak mencemari lingkungan maupun badan air.

c. Kepada pemerintah setempat lebih tegas terhadap industri yang tidak mengelola limbah yang dihasilkan.

\section{DAFTAR PUSTAKA}

Djibran, A., Isa, I., \& Sihaloho, M. 2015. Fitoremediasi Air Yang Terkontaminasi Fosfat Dengan Menggunakan Tanaman Teratai (Nymphea Sp). (Online) : http://eprints.ung.ac.id/10354/. Diakses pada tanggal 5 Januari 2017. 
Jurnal Sulolipu : Media Komunikasi Sivitas Akademika dan Masyarakat

Vol. 17 No.II 2017

e-issn : 2622-6960, p-issn : 0854-624X

Hadiyanto, \& Christwardana, M. 2012. Aplikasi Fitoremediasi Limbah Jamu Dan Pemanfaatannya Untuk Produksi Protein. (Online): https://www.academia.edu/5829385/A PLIKASI_FITOREMEDIASI_LIMBAH_JAMU_DAN_PEMANFAATANNYA_UNTUK_PRO DUKSI_PROTEIN. Diakses pada 10 Januari 2017.

Jenie, B. S. L., \& Rahayu, W. P. 1996. Penanganan Limbah Industri Pangan. Yogyakarta: Kanisius.

Muhajir, M. S. (2013). Penurunan Limbah Cair BOD dan COD pada Industri Tahu Menggunakan Tanaman Cattail

(Typha Angustifolia) dengan Sistem Constructed Wetland.(Online): http://lib.unnes.ac.id/18265/ 1/4350408054.pdf. Diakses pada tanggal 10 Januari 2017.

Nindra, D. Y., \& Hartini, E. 2015. Efektivitas Tanaman Teratai (Nympahea Firecrest) Dan Eceng Gondok (Eichhornia Crassipes) dalam Menurunkan Kadar BOD (Biochemical Oxygen Demand) pada Limbah Cair Industri Tahu. Jurnal Kesehatan. (Online): http://publikasi.dinus.ac.id/index.php/visikes/article/view/1197/900. Diakses pada tanggal 13 Januari 2017.

Rahmah, \& Mulasari, S. A. 2015. Pengaruh Metode Koagulasi, SedimentasidanVariasiFiltrasi terhadap Penurunan Kadar TSS, COD dan Warna pada Li mbah Cair Batik. (Online): https://doi.org/http://journal.uad.ac.id/index.php/CHEMICA/artic le/view/4560/3055. Diakses pada tanggal 5 Januari 2017

Republik Indonesia. 2010. Peraturan Gubernur Sulawesi Selatan Nomor: 69 Tahun 2010 Tentang Baku Mutu dan Kriteria Kerusakan Lingkungan Hidup.

Siswandari, A. M., \& Hindun, I. 2016. Echinodorus Paleafolius Sebagai Tanaman Fitoremedian Dalam Menurunkan Phospat Limbah Cair Laundry. (Online): https://media .neliti.com/media/publications/117737-ID-none.pdf. Diakses pada tanggal 17 Januari 2017. 